\title{
Student Preferences for Learning Resources on a Land-Based Postgraduate Online Degree Program
}

\author{
Duncan Royd Slater \\ Myerscough College, Lancashire, UK \\ Richard Davies \\ University of Central Lancashire, UK
}

\begin{abstract}
Creating engaging online resources is an important part of the rapidly changing discipline of etutoring. There is increasing use of a wide range of media for online training but only a limited number of studies assessing their effectiveness. This study involved an educator working collegiately with cohorts of online students studying a specialist land-based postgraduate degree program $(n=79)$. The opinions of these mature online students, on current and potential learning resources, informed two interventions that provided novel online resources to the course. Student opinion on these new resources was captured and subjected to thematic analysis. The results identify that these students' favored resources were online lectures, course notes, primary literature, and tutors' opinion pieces because they were perceived as accessible, easy to engage with, assignment-related and/or provided something akin to a 'university campus experience'. In contrast, podcasts and knowledge review quizzes were strongly disfavored by the majority of respondents. The implications of this study in relation to online teaching practice are discussed.
\end{abstract}

Keywords: learning resources; online learning; online lectures; podcasts

Slater, D.R. \& Davies, R. (2020). Student preferences for learning resources on a land-based postgraduate online degree program. Online Learning, 24(1), 140-161. https://doi.org/10.24059/olj.v24i1.1976

\section{Student Preferences for Learning Resources on a Land-Based Postgraduate Online Degree Program}

Part of the international market in Higher Education (HE) is an increasing number of highly specialist postgraduate programs whose feasibility depends on global recruitment. For specialist colleges, in this study in land-based studies, maximizing involvement in this global postgraduate market enables sufficient "economies of scale." Further, the global recruitment enables a large enough cohort of students to be recruited to ensure a "learning community" of peers. The program on which we focus links together individuals working in a similar profession (urban forestry) in 
order to develop mastery in their professional role. It is worth noting that these postgraduate students are often already the local expert. The development of internet associated technologies (IATs) has supported the improvement of such courses. Here we report on a review of the resource preferences for a group of such students. The students, drawn from six countries, are work-based and are enrolled on one of very few specialist master's level programs in the field. Although they all have sufficient English skills to access the course, individual levels of English ability and opportunities to use English are variable. For most of the students the choice of distance learning results from a lack of viable alternatives rather than a commitment to distance learning per se. Although not unique, this type of program and student cohort characteristics are in need of further, more specific research. In this paper we focus on students' perspectives on online learning resources.

For online vocational courses to be effective, ongoing review of their online learning resources is essential (Anderson, 2008). Such reviews need to engage with students' perspectives and consider the impact of a range of online learning resources in relation to the students' study behaviors (Palloff \& Pratt, 1999; Means et al., 2009; Redmond et al., 2018). Here we report on a two-stage design to elicit students' perspectives on the use they make of the present resources and what other resources they would use. In stage one, four cohorts of students $(n=79)$ completed a questionnaire and a sample $(n=15)$ were interviewed to ascertain students' views on the present resources. In stage two, we designed two interventions in relation to two different submodule learning units. The first offered the same content in multiple, different online formats. The second offered different content in different online formats. Students used these resources as a normal part of their learning and were invited to comment on the usefulness of the resources in a postintervention questionnaire.

Following a review of the extant literature related to online learning, we will set out more formally our research design. We will then review the data from stage one and then stage two of the study before identifying some key implications for course leaders and learning designers for these types of programs and students.

\section{Review of Related Literature}

\section{The Experience of Studying Online}

If you are part of that minority that chooses to take your degree online, what is the learning experience like? Much research has reported that online study is often seen as a poorer form of delivery of HE courses than on-campus study, both by students and tutors (e.g., Picciano, 2002; Vonderwell, 2003; Song et al., 2004; Muilenberg \& Berge, 2005; Weller, 2007; Cole et al., 2014; Gillett-Swan, 2017). A key factor contributing to this perception, of online study being a 'lesser experience', is the isolation of the online learner (Selwyn et al., 2006). Another major consideration is that regular communication between student and tutor is considered critical for the success of an online course (Beaudoin, 2002; Beuschel et al., 2003; Augar et al., 2006). Previous research, particularly in the 1990s and early 2000s, highlighted that online courses can suffer from high drop-out rates when compared to their on-campus equivalents (Fisher, 2003; Palloff \& Pratt, 2003; MacDonald, 2006). Withdrawals from programs are associated not only with feelings of isolation and lack of communication with tutors, but also whether the course is relevant to the learner and whether student support systems are put in place (Lee et al., 2011). 
Specialist literature on e-learning seeks to address these issues of isolation, lack of communication and subsequent student drop-out. For example, several authors point to the potential for online students to have greater autonomy for their studies (e.g., Lockwood \& Gooley, 2001; MacDonald, 2006; Smith, 2008) and the flexibility of asynchronous online delivery is highlighted as giving more choice and more control of their learning to the online student (Inglis et al., 2002; Gillani, 2003; Conrad \& Donaldson, 2004). In addition, some authors speculate that online learning, if developed in a suitable way, can be more student-centered than typical oncampus teaching at a university (Forsyth, 2001; Richardson, 2006; Weller, 2007). Some key characteristics of an effective online student and her/his online learning community that emerge from educational literature are presented in Figure 1.

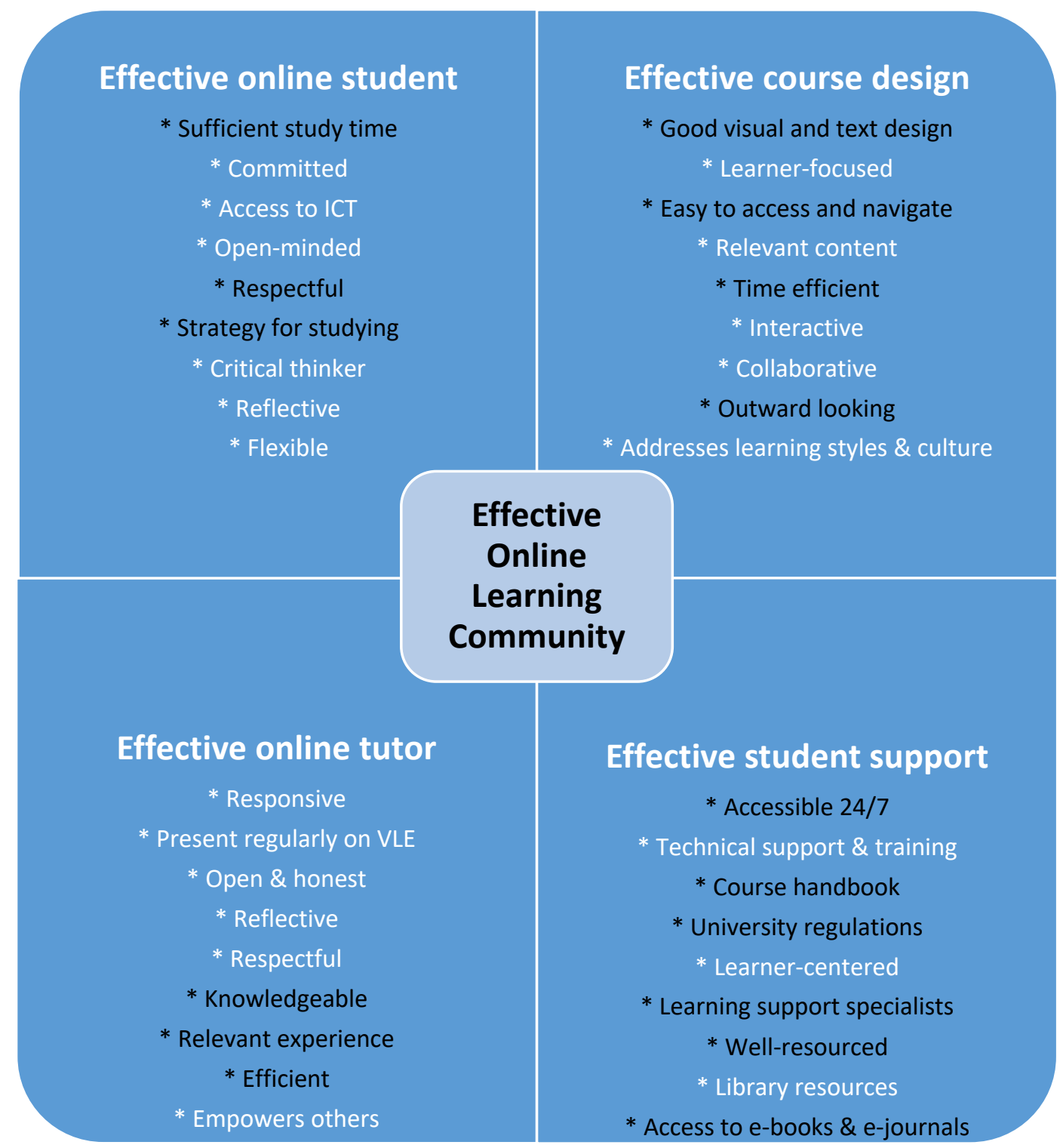

Figure 1. Key factors in building of an effective online learning community. Adapted from Palloff \& Pratt (2003). Amendments are displayed in black text. 


\section{Creating Effective Learning Resources for Online Courses}

There are a considerable number of instructional texts, aimed at tutors and course managers, on the creation of engaging online learning materials (e.g., Palloff \& Pratt, 2003; Race, 2005; Bonk \& Zhang, 2008; Garrison \& Anderson, 2011). Unfortunately, due to the fast pace of change in software and virtual learning environment (VLE) capabilities, some sections of such texts become rapidly dated. This fast-developing method of course delivery presents a considerable number of challenges to both the provider and to the cohorts of students engaged with online learning (McVay-Lynch, 2002). For instance, the last decade has seen a move towards compatibility of online resources with mobile technology which results in students having their university courses 'in their pocket' (Sharples et al., 2006; Bell, 2008). Creating bespoke resources, ensuring there is formative assessment, and providing motivational rewards for undertaking these formative assessments is recommended (Gillani, 2003). Seale et al. (2007) see the challenge of creating new online learning resources as three-fold, they should be designed for learning, highly accessible \& highly reusable. In addition, Martin and Bolliger (2018) emphasise that interactions between the learner, other learners, course resources and tutors is of critical importance for good student engagement.

There are several studies that found the use of audio/visual learning resources for online learners to be effective, especially the use of instructional video and online lectures (MacPherson \& Nunes, 2004; Mitra et al., 2010; Borup et al., 2011; Carmichael et al., 2017; Crook \& Schofield, 2017; Scagnoli et al., 2017). Although now a popular delivery format in online courses, moving away from a high level of reading content, Pomales-Garcia and Liu (2006) warn against providing overlong videos or lectures. Their research highlights that online learners were less likely to complete modules with resources that took longer for them to work through. For some online provision, the use of synchronous webinars has become more common. These allow students to interact whilst an online lecture is being delivered (Moore \& Kearsley, 2012). It is a format which comes closest to simulating an interactive lecture hall environment. In addition to these audio/visual offerings, some researchers have assessed the impact of podcasts as online learning materials (Richardson, 2006; Salmon, 2008; Lawlor \& Donnelly, 2010). Lawlor and Donnelly (2010) found that podcasts were extensively used by a proportion of postgraduate students taking an online course, making them a valuable form of differentiation.

Although there is a consensus that students gain from a planned program of high quality, well-tested online learning resources, Bonk (2001) found, through surveying online tutors, that less than $40 \%$ of sampled online courses contained the interactive elements that the tutors themselves stated would be valuable for their students. In addition, Kinash et al. (2015) state that there is a lack of empirical evidence in relation to the effectiveness of the technologies used for online teaching. They concluded, from their meta-analysis of online student experiences, that this is a key knowledge gap. This study explores aspects of this identified "knowledge gap" within the specific context of an educator providing bespoke online learning resources to students on a specialized postgraduate course. 
This action research study was framed around two interrelated research questions:

RQ1 Of the current online resources on a selected postgraduate course, which did the students use most frequently, and for what reasons?

RQ2 Of the newly generated online resources created for the two interventions in this study, which did the students use more frequently, and for what reasons?

\section{Methods}

Participants in this study were enrolled on a specialist online master's degree course in arboriculture and urban forestry, delivered by Myerscough College on behalf of the University of Central Lancashire (UCLan). In addition to present students, a cohort of ex-students who had just completed the qualification were invited to be involved with the interview phase of the study. Details of the student cohorts are provided in Table 1.

Table 1

Breakdown of Participating Student Cohorts in terms of Year Groups, Numbers of Students in Each Cohort, Nationalities in Each Cohort and Gender Mix

\begin{tabular}{cccc}
$\begin{array}{c}\text { Student } \\
\text { Cohort }\end{array}$ & $\begin{array}{c}\text { Number of } \\
\text { Students }\end{array}$ & $\begin{array}{c}\text { Student } \\
\text { Nationalities }\end{array}$ & Student Gender \\
\hline First Years & 35 & $\begin{array}{c}\text { 9 British; 25 Hong } \\
\text { Kongese: 1 Singaporean }\end{array}$ & 14 Female, 21 Male \\
Second Years & 11 & $\begin{array}{c}\text { 5 British; 1 Canadian; 4 } \\
\text { Hong Kongese; 1 Irish }\end{array}$ & 3 Female, 8 Male \\
Third Years & 15 & $\begin{array}{c}\text { 5 British; 2 Canadian; 1 } \\
\text { Croatian; 7 Hong Kongese }\end{array}$ & 7 Female, 8 Male \\
Ex-Students & 18 & $\begin{array}{c}\text { 8 British; 1 Canadian; } 9 \\
\text { Hong Kongese }\end{array}$ & 7 Female, 11 Male \\
& & \multicolumn{3}{c}{}
\end{tabular}

An initial online questionnaire (created within SurveyMonkey ${ }^{\circledR}$ and provided in Appendix 1) asked participants about their views of the learning resources they had previously had access to on the course (Table 2). 
Table 2

Current Learning Resources used in this Postgraduate Course.

\begin{tabular}{l} 
Learning Resource \\
\hline 1. Online lectures \\
2. Academic papers \\
3. Knowledge review \\
quizzes
\end{tabular}

5. Further reading

6. Tutor's own papers

7. External links

\section{Discussion board}

9. Announcements

\section{Form of resource}

Slideshows with accompanying audio, most with a script to view. These were created in Adobe Presenter $^{\circledR}$, OfficeMix ${ }^{\circledR}$, or Powerpoint ${ }^{\circledR}$.

Journal papers - typically in PDF format - selected by the tutors to be the most relevant for the topic being covered in that teaching session.

Created within the VLE, these quizzes focused on reviewing knowledge gained from reading the academic paper(s) highlighted in each session.

A concise, illustrated article by the tutor on a contentious and contemporary topic - typically in PDF format.

A range of documents, mainly PDF and Word ${ }^{\mathbb{R}}$ documents.

Some module tutors have authored their own research papers. Where these are relevant to modules, they are provided to students (typically as PDF files).

Links to other websites and external learning resources selected by the tutor.

In-built discussion board within the VLE, where students and tutors can create, read and answer discussion threads.

A messaging system used by tutors to contact the whole of an online class of students, in-built to the VLE.
Accessibility

Not downloadable - could only be viewed when the student was logged into the VLE.

Downloadable \& could be viewed on a range of devices.

Not downloadable - could only be undertaken when the student was logged into the VLE.

Downloadable \& could be viewed on a range of devices.

Downloadable \& could be viewed on a range of devices.

Downloadable \& could be viewed on a range of devices.

Would initially have to be accessed via the VLE but then can be saved and accessed independently.

Could only be accessed via the VLE.

Announcements are viewable within the VLE but are also sent out to student email addresses. 
This initial questionnaire finished with a question to ascertain students' preferences for new learning resources that the tutor could create for them. This was a closed question of predefined options scored by participants using a Likert scale. Further, fifteen students across the four cohorts participated in an online, semi-structured interview to obtain more in-depth views on their learning experience on the course and their reasons for favoring some learning resources over others. The framework of questions asked in these interviews is provided in Appendix 2.

Data from both these processes fed into the creation of new learning resources for two distinct interventions during the delivery of the course program. The first intervention involved supplying the same content in a range of different formats (online lecture, course notes, video, streamed video, and podcast) for students to trial. The second intervention involved supplying a wider range of formats for learning materials with each new resource distinct from any other in terms of content (Table 3). The rationale behind this approach was to seek to separate the students' preferences for different media formats from the effectiveness of unique learning objects due to their form and content.

\section{Table 3}

Details of the Learning Resources Produced for the Second Intervention of this Study, Providing Learning Resource Titles, Type, and File Format.

\section{Learning Resource}

$\begin{array}{lc}\begin{array}{l}\text { The urban forest of downtown } \\ \text { Singapore }\end{array} & \begin{array}{l}\text { Online lecture } \\ \text { Trees as biotechnology }\end{array} \\ \begin{array}{l}\text { People love trees } \\ \text { Landscaping of Birchwood Park, } \\ \text { Warrington }\end{array} & \begin{array}{c}\text { Tutor's Viewpoint } \\ \text { The urban forest of Aarhus, }\end{array} \\ \begin{array}{l}\text { Denmark } \\ \text { From the front line (concerning } \\ \text { recent science about urban forests) } \\ \text { The urban forest of Pistoia, Italy }\end{array} & \text { Online lecture } \\ \end{array}$

Also made available as a downloadable video (MP4)

PDF file

PDF file

MP4 file

Available for download

Also made available as a downloadable video (MP4)

MP3 file

Available for download

Also made available as a downloadable video (MP4)

Academic paper PDF File

Tutor's Viewpoint PDF File

Video taken outdoors

MP4 File

Available for download

Links to other

Links embedded in the VLE websites session page 
These two interventions were followed up with a final questionnaire (created within SurveyHero ${ }^{\circledR}$ and supplied in Appendix 3) sent to all students who had participated in the intervention $(n=63)$, which asked them to evaluate their experience of the new online resources provided via the two interventions. A timeline for the key actions in this study is provided in Figure 2.

\section{Data Collection and Analysis}

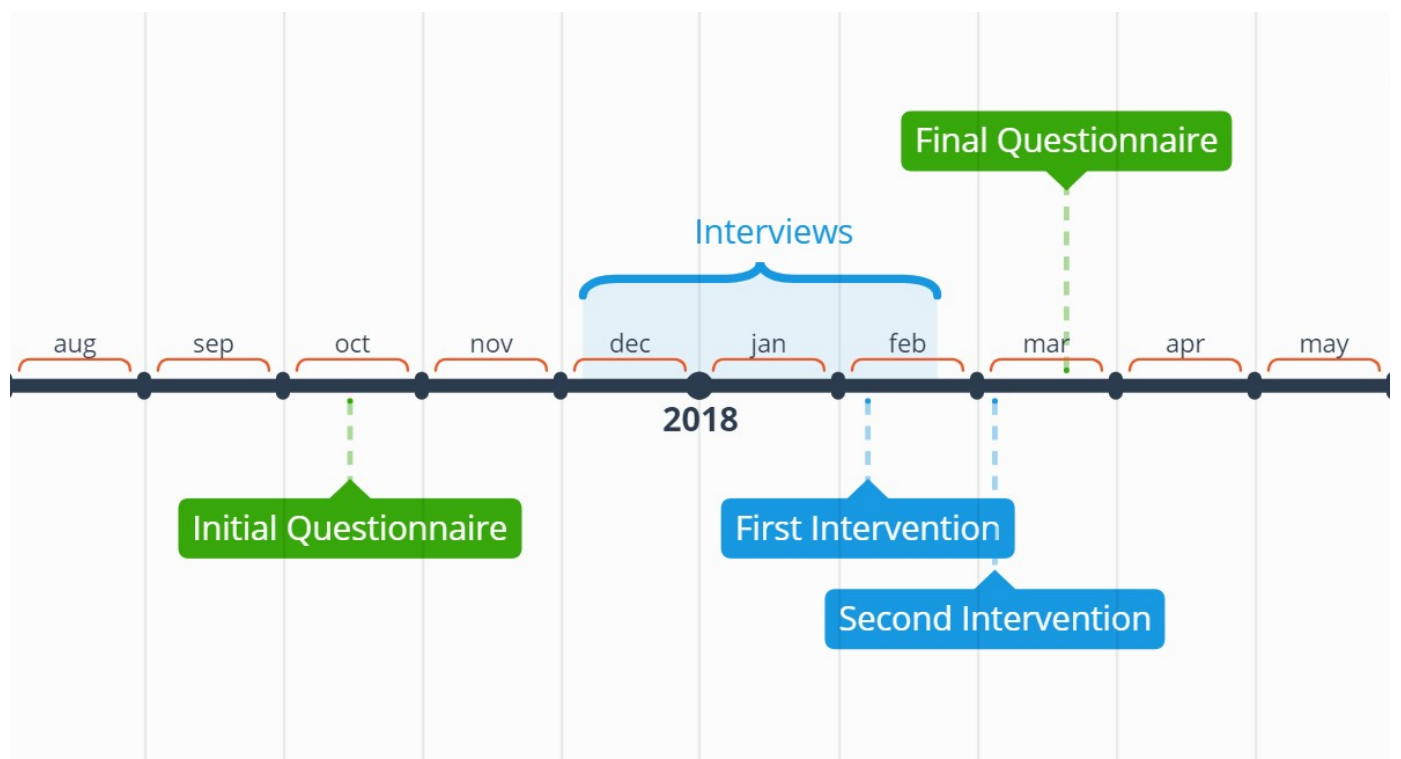

Figure 2. Timeline illustrating the four key phases of this study: an initial questionnaire, semi-structured interviews, two interventions, and a final questionnaire.

This self-reporting approach to data capture was considered effective in answering our research questions. The respondents in this case were all mature learners in professional roles who had a good rapport with the lead researcher. The discussions during the interviews where consistent with the responses in the questionnaire, with previous module evaluations and reflections of the course team. Answers were also consistent with known VLE metrics of students' use of existing resources. The research itself was articulated to participants as part of the resource development for the course. Care was taken to ensure that participants were aware that there was no "correct" answer and that involvement in the study would not impact on their learning or assessment. The study gained ethical approval at UCLan.

The responses from the semi-structured interviews and open questions within the questionnaires were first coded then themed (Burton et al., 2008). The theming of responses was reiterated three times to achieve conjoining of similar themes and to identify emergent and more specific themes that were initially placed within broader themes (Tracy, 2013). Relevant insightful quotes were selected to provide supporting evidence for the thematic analysis (Galletta, 2013). The closed, Likert scale questions were analyzed utilizing nonparametric, one-way analysis of variance. 


\section{Results and Discussion}

\section{Initial questionnaire}

The initial questionnaire received forty responses across the three cohorts of current students, representing a response rate of $54.8 \%$. Figure 3 provides the outcomes when students were asked which current online resources they found most efficient and effective for their learning. A Kruskal-Wallis and post-hoc Mood's Median test identified that there were significant differences in the rating of these resources by these respondents $(H=69.21 ; d f=6 ; p<0.001)$.

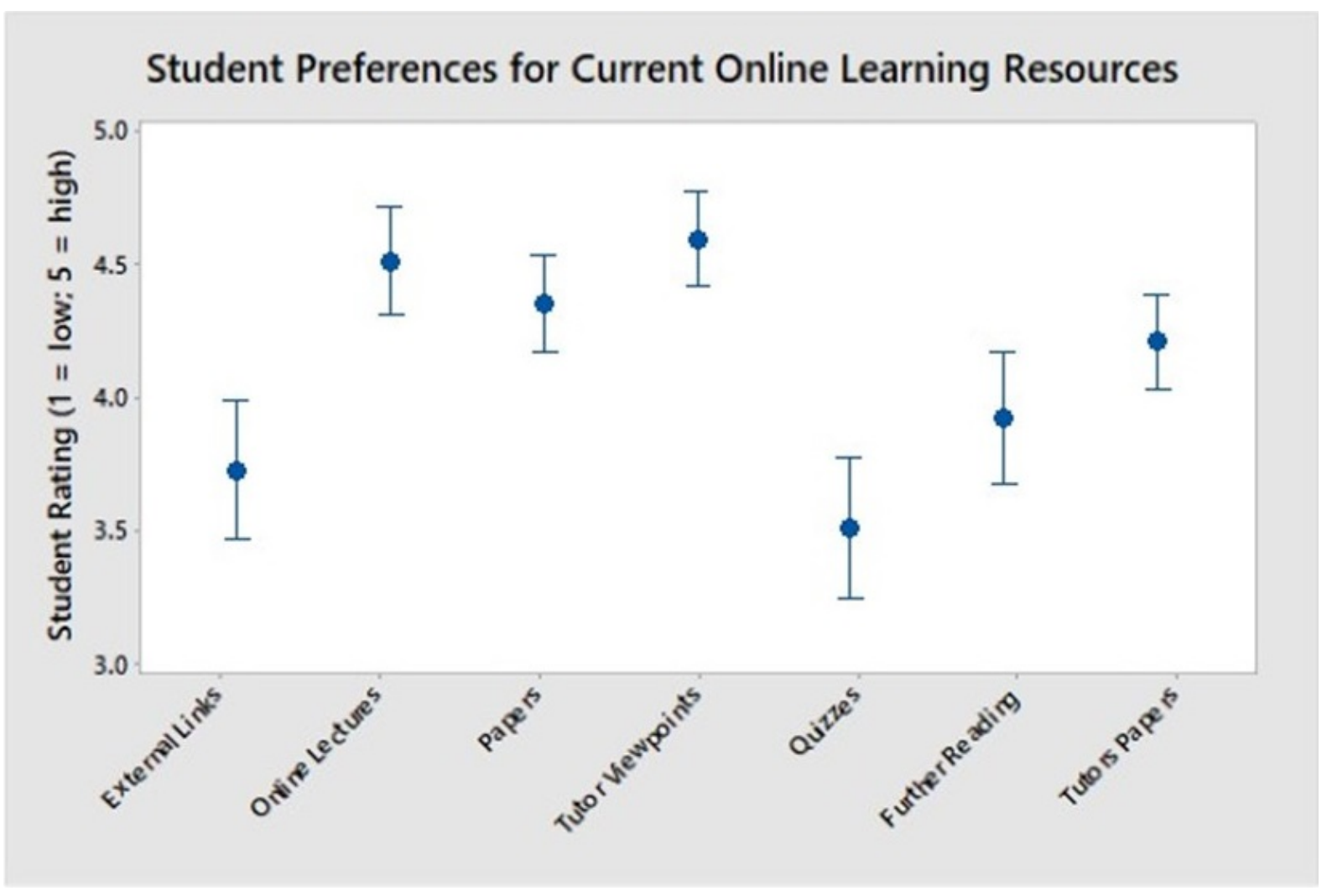

Figure 3. Student preferences, expressed via a rating scale from 1 (low) to 5 (high), for the range of current learning resources offered on the postgraduate course.

Knowledge review quizzes scored the lowest in terms of preferences, so, without highlighting this to the participants, these quizzes were omitted from the learning resources created for the two interventions. As we note shortly, students did not mention missing these resources during the intervention.

An open question about student preferences in terms of existing resources elicited a clear preference for the online lectures (Table 4), but the creation of course notes was the highest-scoring preference for new learning materials. This latter preference is probably best explained by this course being predominantly delivered via online lectures at that time. Therefore, the addition of course notes had the potential to diversify the learning materials. In addition, some students stated a preference for more reading materials rather than for further audio/visual resources to be created. They cited that their high reading speeds made this form of learning resource efficient for their learning and that they could read away from their computer. 
Table 4

Students' Stated Most-used Current Online Resources (n = 40), Showing Frequency of Preference, Coded Themes, and Selected Student Comments

\begin{tabular}{|c|c|c|c|}
\hline $\begin{array}{l}\text { Most used } \\
\text { resource }\end{array}$ & Frequency & Coded themes & Selected student comments \\
\hline Online lectures & 25 & $\begin{array}{l}\text { Ease of use } \\
\text { Key information } \\
\text { Relevant } \\
\text { Concise } \\
\text { Guide to learning } \\
\text { Enjoyable } \\
\text { Unique } \\
\text { Like attending Uni }\end{array}$ & $\begin{array}{l}\text { "Because I am in full time employment and } \\
\text { this is the easiest format to use." } \\
\text { "It gives me an introduction into the } \\
\text { topic/subject matter and helps explain key } \\
\text { elements." } \\
\text { "This kind of resource is a more interesting } \\
\text { learning material, which summarize the } \\
\text { content of the lesson." } \\
\text { "It cannot be found elsewhere." } \\
\text { "Mimics a real lecture. I learn best from } \\
\text { either physically doing something (difficult } \\
\text { with an online course!) or verbal } \\
\text { communication. Online lectures are as } \\
\text { close as one can get to real life university." }\end{array}$ \\
\hline $\begin{array}{l}\text { Academic } \\
\text { papers }\end{array}$ & 11 & $\begin{array}{l}\text { Research links } \\
\text { Key information } \\
\text { Specific } \\
\text { Assignment- } \\
\text { related } \\
\text { Accessibility } \\
\text { Up-to-date }\end{array}$ & $\begin{array}{l}\text { "It provides a strong basis to the study of } \\
\text { the particular topic. Other references and } \\
\text { searches can then be undertaken." } \\
\text { "It can be accessed anytime, anywhere." } \\
\text { "Very informative." }\end{array}$ \\
\hline $\begin{array}{l}\text { Tutor's } \\
\text { viewpoints }\end{array}$ & 3 & $\begin{array}{l}\text { Specific } \\
\text { More usable } \\
\text { Assignment- } \\
\text { related }\end{array}$ & $\begin{array}{l}\text { "Tailored to the specific module and } \\
\text { provides a good overview and insight into } \\
\text { the key elements that are being explored." }\end{array}$ \\
\hline $\begin{array}{l}\text { Further } \\
\text { Reading }\end{array}$ & 1 & Scientific evidence & "Good for knowing the latest research." \\
\hline
\end{tabular}

Note. Coded themes are ordered such that the most frequently-occurring themes are at the top of each list.

\section{Semi-structured interviews}

The interview process gave rise to much "rich data" and only a small proportion can be reported here. Three main learning resources were mentioned as the students' most-favored resources: the online lectures $(n=13)$, tutor's viewpoints $(n=8)$, and the academic papers $(n=6)$. 
The knowledge review quizzes were mentioned as helpful by two interviewees and no other online resources were mentioned (i.e., external links and further reading).

Key themes relating to online learning resources are provided here, with example quotes from interviewees.

- A limited use of the online discussion board: "I didn't tend to contribute, but I read all the contributions to the discussion board. It was interesting to see what the other students were thinking. Most of the student contributions were well-written and they had quite interesting perspectives. I could not often add to what was being said."

- A preference for online lectures: "I mostly use online lectures, tutor viewpoints and related research. Most of all I favor online lectures as they guide you through the topic and they are easier to consume than written text, especially scientific articles."

- Low usage of knowledge review quizzes: "Quizzes-I use the least. When I am time-poor, these are not essential."

- Mixed views on suitable formats for future learning resources: "I already listen to podcastsusually when I am doing something mundane like the washing-up-so I can take it in. If you do sit down to study, though, you want the audio/visual-something to look at as well as to listen to. Videos could also be good, for clarifying things further."; Respondent B: "I am not used to using podcasts - they are not needed for me-I wouldn't use them. The slides and online lectures work well for me. I can see video being of some use-for example, to look at hazardous trees" (Respondent A).

\section{Final questionnaire}

The final questionnaire was completed by eighteen students on the course program. Their responses on preferred learning resources from Intervention One are provided in Table 5. In this intervention the same content was provided in several different formats.

In the first intervention, the online lectures were most-favored and received no critical comments. The podcast received the most criticism as a learning resource. Downloadable video received the most mixed reviews. It required the largest data allowance on the students' devices, but some respondents felt that it gave the best viewing performance. Some of these differences can be traced to the level of English language of the students. Students whose reading and comprehension ability was higher than their oral comprehension preferred written texts. It was also clear that in some contexts certain resources could more easily be used, surreptitiously, in "work time," and hence were preferred. 


\section{Table 5}

Student Views on the Formats of Learning Resources-Intervention One ( $\mathrm{n}=18)$

\begin{tabular}{|c|c|c|c|}
\hline $\begin{array}{l}\text { Positive } \\
\text { Responses }\end{array}$ & Frequency & Coded themes & Selected student comments \\
\hline $\begin{array}{l}\text { Course } \\
\text { Notes }\end{array}$ & 5 & $\begin{array}{r}\text { Accessible } \\
\text { Efficient } \\
\text { Supporting }\end{array}$ & $\begin{array}{l}\text { "I used less than five minutes to read the new learning resource } \\
\text { PDF. While I watch the video, although I change the speed to } 2 \mathrm{x}, \mathrm{I} \\
\text { still have to use fifteen minutes. Reading is always more efficient } \\
\text { for me." } \\
\text { "As a foreign student, understanding of English might be difficult } \\
\text { at some point. } \\
\text { The course notes will be a great help to understand both } \\
\text { presentation and video." }\end{array}$ \\
\hline $\begin{array}{l}\text { Online } \\
\text { Lecture }\end{array}$ & 10 & $\begin{array}{r}\text { Effective } \\
\text { Like attending } \\
\text { Uni } \\
\text { Note-taking } \\
\text { Stimulating } \\
\text { Tutor emphasis }\end{array}$ & $\begin{array}{l}\text { "It is the closest imitation mode to being in the class physically." } \\
\text { "I preferred the audio/visual presentation as this is the most like a } \\
\text { lecture and got me in the mindset of studying." }\end{array}$ \\
\hline $\begin{array}{l}\text { Audio } \\
\text { Podcast }\end{array}$ & 2 & $\begin{array}{r}\text { Accessible } \\
\text { Convenient }\end{array}$ & $\begin{array}{l}\text { "I enjoyed the ability to listen to the podcast whilst doing my day- } \\
\text { to-day work." }\end{array}$ \\
\hline $\begin{array}{l}\text { Streamed } \\
\text { Video }\end{array}$ & 1 & $\begin{array}{r}\text { (No specific } \\
\text { positive } \\
\text { comments) }\end{array}$ & $\begin{array}{l}\text { "I think the audio/visual presentations were of equal merit. They } \\
\text { were clear and well-structured." }\end{array}$ \\
\hline $\begin{array}{l}\text { Video } \\
\text { Download }\end{array}$ & 7 & $\begin{array}{r}\text { Accessible } \\
\text { IT } \\
\text { compatibility } \\
\text { Technically } \\
\text { superior }\end{array}$ & $\begin{array}{l}\text { "Smooth watch experience." } \\
\text { "My first choice would be the MP4, which had the best resolution } \\
\text { and works on all devices." }\end{array}$ \\
\hline
\end{tabular}

\section{Negative}

Responses

Course

Notes

Online

0

Lectures

Podcast

Streamed

Video

Video

Download
3

6 Lesser resource

No images

Not effective

Poor screen

size

Poorer format

Data uploading

Not essential

\section{Selected student comments}

"I avoided downloading the course notes. I prefer using audio/visual and making my own notes which I find easier to reference for assignments."

\section{No comments received}

"No pictures and no words to read."

"Podcast—not funny."

"Had no need to listen to them on the move/remotely."

"Just preferred resources that are better for using."

"Time consuming to download, used much of my internet data allowance."

"Didn't use the downloadable videos - didn't see the advantage when the audio/visual presentation works fine." 
Table 6

Student Views on the Learning Resources-Intervention Two ( $\mathrm{n}=18)$

\begin{tabular}{|c|c|c|c|}
\hline Positive Responses & Frequency & Coded themes & Selected student comments \\
\hline Academic Papers & 1 & Assignment-related & $\begin{array}{l}\text { "Academic paper helps us to have a better direction on what } \\
\text { we should include in our assignment." }\end{array}$ \\
\hline Online lectures & 9 & $\begin{array}{r}\text { Effective } \\
\text { Good quality } \\
\text { Knowledge } \\
\text { Like attending Uni }\end{array}$ & $\begin{array}{l}\text { "Online lecture with script - easier to follow and get the } \\
\text { points easier." } \\
\text { "Audio and video more suits my learning style from which I } \\
\text { can make my own notes for future reference." }\end{array}$ \\
\hline Outdoor Video & 4 & $\begin{array}{r}\text { Engaging } \\
\text { Real World }\end{array}$ & $\begin{array}{l}\text { "Encourages myself to process what I am seeing and filter it } \\
\text { in my brains, as I understand that ideas are linked and can be } \\
\text { organized and associated." }\end{array}$ \\
\hline Podcast & 0 & Ineffective & $\begin{array}{l}\text { "Podcasts require the lecturer to be more descriptive to fill in } \\
\text { the gaps to be effective." }\end{array}$ \\
\hline Streamed Video & 0 & (No comments) & No comments \\
\hline Tutor's Viewpoints & 5 & $\begin{array}{r}\text { Accessible } \\
\text { Critique } \\
\text { Efficient } \\
\text { Good Content }\end{array}$ & $\begin{array}{l}\text { "Tutor's viewpoint - in this case, the alternative, thought- } \\
\text { provoking take on the topic was very useful as it helped in } \\
\text { forming a more objective standpoint." }\end{array}$ \\
\hline Video Download & 4 & $\begin{array}{r}\text { Accessible } \\
\text { Technically better }\end{array}$ & $\begin{array}{l}\text { "I prefer the MP4 due to the quality and flexibility of the } \\
\text { format." }\end{array}$ \\
\hline No Preference & 3 & $\begin{array}{r}\text { Does not matter } \\
\text { Liking all formats }\end{array}$ & $\begin{array}{l}\text { "Not specific, all formats would be acceptable as long as it is } \\
\text { necessary for the modules." }\end{array}$ \\
\hline Negative Responses & Frequency & Coded themes & Selected student comments \\
\hline Academic Papers & 1 & Difficult to use & $\begin{array}{l}\text { "I use academic papers but I struggle to maintain focus in } \\
\text { trawling through lots of written information." }\end{array}$ \\
\hline External Links & 2 & $\begin{array}{l}\text { Not academic } \\
\text { Not specific }\end{array}$ & "Time consuming to search for specific information." \\
\hline Online Lectures & 0 & $\begin{array}{r}\text { (No negative } \\
\text { comments) }\end{array}$ & No negative comments \\
\hline Outdoor Video & 2 & $\begin{array}{r}\text { Outdoor noises } \\
\text { Quality of content }\end{array}$ & $\begin{array}{l}\text { "The outdoor lecture was a bit more difficult to listen to } \\
\text { because of the environmental conditions and the content } \\
\text { seemed a bit thin compared to the more prepared lectures in } \\
\text { other formats." }\end{array}$ \\
\hline Podcast & 8 & $\begin{array}{r}\text { Ineffective } \\
\text { No images } \\
\text { Potential to } \\
\text { misunderstand } \\
\text { Too long }\end{array}$ & $\begin{array}{l}\text { "This is too casual and cannot get enough of my attention." } \\
\text { "No script and without illustration, I may very likely } \\
\text { misunderstand the meaning." }\end{array}$ \\
\hline Streamed Video & 1 & Lower quality & $\begin{array}{l}\text { "I did not like the low resolution of some of the embedded } \\
\text { video options." }\end{array}$ \\
\hline Tutor's Viewpoints & 1 & $\begin{array}{r}\text { Not assignment- } \\
\text { related }\end{array}$ & $\begin{array}{l}\text { "Tutor's viewpoints I have read before have been interesting } \\
\text { and thought provoking but have not been directly relevant to } \\
\text { the assignment." }\end{array}$ \\
\hline Video Download & 0 & $\begin{array}{r}\text { (No negative } \\
\text { comments) }\end{array}$ & No negative comments \\
\hline $\begin{array}{l}\text { No Preference } \\
\text { between formats }\end{array}$ & 2 & & $\begin{array}{l}\text { "I have no need or desire to use the resources whilst on the } \\
\text { move." }\end{array}$ \\
\hline
\end{tabular}


Table 6 (above) gives the students' views on the resources made available to them in the second intervention.

A very similar pattern of feedback was received for both interventions: that online lectures were most favored (supporting the findings of MacPherson \& Nunes, 2004; Mitra et al., 2010; Borup et al., 2011; Carmichael et al., 2017; Crook \& Schofield, 2017; Scagnoli et al., 2017) and that the podcasts were the most criticized (Lawlor and Donnelly, 2010). Views were mixed on the use of outdoor videos to assess urban trees in the second intervention, some students wanted higher production values in terms of technical content and sound recording. Similar comments were received about the streamed videos, where lower quality was a key limitation.

No respondents commented on the absence of the knowledge review quizzes that had been consistently provided in all previous eleven teaching sessions of this module. This strongly suggests that these formative assessments were not a highly valued learning resource for these students.

\section{Conclusions}

The findings of this study should be understood in the specific context of a specialist online course on a technical topic at postgraduate level. It is considered likely that the ages, previous educational backgrounds, and English language ability of the students who participated in this study will have had a strong bearing on the results reported here.

The initial questionnaire in this study identified three current resources that were significantly more favored than the others: online lectures, academic papers, and tutor's viewpoints. These resources were conceived to be key elements of the teaching provision for this MSc course program by its tutors - so this instructional design was strongly supported by the students' views $(n=40)$. A continuing preference for these resources was shown after both interventions $(n=18)$, identifying that successful course delivery should involve a mix of audio/visual resources with ample written resources. The responses received provided a clear answer to our two research questions. These postgraduate students appreciated the mix of learning resource types made available to them but showed strong preferences toward the use of online lectures, reading primary literature and having bespoke course-related notes or articles.

In terms of creating an effective online learning community (Figure 1), this study elicited responses in a number of key areas that may be relevant to other practitioners. At this postgraduate level, critical thinking is a key expectation of students' work. Students valued the "Tutor's viewpoints" in the course materials because this learning resource always provided a critical stance on key topics from which students could develop their own views and opinions. Provided in written form (PDF files), it was the critical content that the students valued; there were no comments on this being a less valuable learning object because of its medium. A number of responses on a range of learning resources provided, showed there was a clear focus on relevant content over medium. Students valued the flexibility of their studies but only a few expressed an interest in the use of the podcasts. Those that did emphasized that they "freed them from the screen." The majority of these students, however, did not like this medium. We would recommend that it should only be provided as a means of minor differentiation, providing the same content as, say an online lecture or course notes in a format that suits only a minority. 
Other suggested key attributes of an effective online course, in terms of its learning materials, are that they should be learner-focused, interactive and collaborative (Figure 1). The most interactive elements of the current course were considered by the tutor to be the review quizzes and the discussion board but these were not favored by the students. They often stated a strong, individualistic focus on gaining new knowledge for themselves rather than on interaction or collaboration. The quizzes in their current format were clearly ineffective learning resources. They were both rated low on the initial questionnaire and were not missed by students when they were omitted from the second intervention. This may be because they were provided as knowledge reviews on specific reading material. We are intending to trial alternative interactive quizzes with different foci to see if it was their original specificity that was off-putting to students. Likewise, adjusting the "rules" of the discussion board may lead to a better level of interaction. For example, we are considering allowing anonymous postings or pseudonyms for students so they feel less daunted about using this collaborative tool or by making engagement with the discussion board compulsory (Malkin et al., 2018).

An online course designer or tutor should act to empower their students by creating flexible, interactive, attractive, and content-rich learning resources that leads to stronger engagement by the students on the course (Redmond et al., 2018). This study has reported on one: an iterative cycle of learning object creation, appraisal, and user feedback. The knowledge acquired has provided a more nuanced understanding of the ways in which individuals, on this program, value and utilize the resources made available to them. Our findings have resonated with tutors delivering other online postgraduate programs to mature, work-based learners. The broad learning from this work is twofold. Firstly, that care is needed in transferring general research in online learning to specialist, atypical, groups of learners. Secondly, that an iterative cycle of reviewing resources brings educational and financial benefits to tutors delivering online courses. As a result of this work time and effort has been more effectively directed towards the generation of appropriate and engaging online learning resources. 


\section{References}

Anderson, T. (Ed.) (2008). The theory and practice of online learning (2nd edition). Alberta University Press.

Augar, N., Raitman, R., Lanham, E., \& Zhou, W. (2006). Building virtual learning communities. In Z. Ma (Ed.), Web-based intelligent e-learning systems:Technologies and applications (pp. 72-100). Information Science Publishing.

Beaudoin, M. F. (2002). Learning or lurking?: Tracking the "invisible" online student. Internet \& Higher Education, 5(2), 147-155.

Bell, D. (2008). The university in your pocket. In G. Salmon and P. Edirisingha (Eds.), Podcasting for learning in universities (pp. 178-187). OUP.

Beuschel, W., Gaiser, B., and Draheim, S. (2003). Communication needs of online students. In A. K. Aggarwal (Ed.), Web-based Education: Learning from experience (pp. 203-222). Information Science Publishing.

Bonk, C. J. (2001). Online teaching in an online world. CourseShare.

Bonk, C. J., \& Zhang, K. (2008). Empowering online learning: 100+ activities for reading, reflecting, displaying and doing. Jossey-Bass.

Borup, J., Graham, C., \& Velasquez, A. (2011). The use of asynchronous video communication to improve instructor immediacy and social presence in a blended learning environment. In A. Kitchenham (Ed.), Blended learning across disciplines: Models for implementation (pp. 38-57). IGI Global.

Burton, N., Brundrett, M., \& Jones, M. (2008). Doing your education research. Sage Publications Ltd.

Carmichael, M., Reid, A.-K., \& Karpicke, J. D. (2017). Assessing the impact of educational video on student engagement, critical thinking and learning: The current state of play. Sage Publishing Ltd.

Cole, M. T., Shelley, D. J., \& Swartz, L. B. (2014). Online instruction, e-learning and student satisfaction: A three-year study. The International Review of Research in Open and Distributed Learning, 15, 111-131.

Conrad, R., \& Donaldson, J. (2004). Engaging the online learner: Activities and resources for creative instruction. Jossey-Bass.

Crook, C., \& Schofield, L. (2017). The video lecture. The Internet and Higher Education 34, 5664.

Fisher, M. (2003) Designing courses and teaching on the web: A "how-to" guide to proven, innovative strategies. Scarecrow Education.

Forsyth, I. (2001). Teaching and learning materials and the internet (3rd edition). Kogan Page Ltd. 
Galletta, A. (2013). Mastering the semi-structured inteview and beyond: From research design to analysis and publication. New York University Press.

Garrison, D. R., \& Anderson, T. (2011). E-learning in the 21st century: A framework for research and practice (2nd edition). RoutledgeFalmer.

Gillani, B. B. (2003). Learning theories and the design of e-learning environments. University Press of America Inc.

Gillett-Swan, J. (2017). The challenges of online learning: Supporting and engaging the isolated learner. Journal of Learning Design 10(1), 20-30.

Inglis, A., Long, P., \& Joosten, V. (2002). Delivering digitally: Managing the transition to the knowledge media (2nd edition). Kogan Page Ltd.

Kinash, S., Knight, D., \& McLean, M. (2015). Does digital scholarship through online lectures affect student learning? Journal of Educational Technology \& Society, 18(2), 129-139.

Lawlor, B., \& Donnelly, R. (2010). Using podcasts to support communication skills development: A case study for content format preferences among postgraduate research students. Computers \& Education, 54(4), 962-971.

Lee, S. J., Srinivasan, S., Trail, T., Lewis, D., \& Lopez, S. (2011). Examining the relationship among student perception of support, course satisfaction and learning outcomes in online learning. The Internet and Higher Education, 14(3), 158-163.

Lockwood, F., \& Gooley, A. (Eds.) (2001). Innovation in open and distance learning: Successful development of online and web-based learning. Kogan Page Ltd.

MacDonald, J. (2006) Blended learning and online tutoring: A good practice guide. Gower Publishing Ltd.

Malkin, A., Rehfeldt, R. A., \& Shayter, A. M. (2018). An investigation of the efficacy of asynchronous discussion on students' performance in an online research method course. Behaviour Analysis in Practice, 11, 274-278.

Martin, F., \& Bolliger, D. U. (2018). Engagement matters: Student perceptions on the importance of engagement strategies in the online learning environment. Online Learning $22(1), 205-222$.

McVay-Lynch, M. (2002). The online educator: A guide to creating the virtual classroom. RoutledgeFalmer.

Mitra, B., Lewin-Jones J., Barrett, H., \& Williamson, S. (2010). The use of video to enable deep learning. Research in Post-Compulsory Education, 15(4), 405-414.

Means, B., Toyama, Y., Murphy, R., Bakia, M., \& Jones, K. (2009). Evaluation of evidencebased practices in online learning: A meta-analysis and review of online learning studies. Office of Planning, Evaluation and Policy Development, U.S. Department of Education.

Moore, M. G., \& Kearsley, G. (2012). Distance education: A systems view of online learning (3rd edition). Cengage Learning. 
Muilenburg, L. Y., \& Berge, Z. L. (2005). Student barriers to online learning: A factor analytic study. Distance Education, 26, 29-48.

Palloff, R. M., \& Pratt, K. (1999). Building learning communities in cyberspace: Effective strategies for the online classroom. Jossey-Bass.

Picciano, A. G. (2002). Beyond student perceptions: Issues of interaction, presence and performance in an online course. Journal of Asynchronous Learning Networks, 6(1), 21-40.

Pomales-Garcia, C., \& Liu, Y. (2006). Web-based distance learning technology: The impacts of web modules' length and format. American Journal of Distance Education, 20(3), 163-179.

Race, P. (2005). 500 tips for open and online learning (2nd edition). RoutledgeFalmer.

Redmond, P., Heffernan, A., Abawi, L.-A., Brown, A., \& Henderson, R. (2018) An online engagement framework for higher education. Online Learning, 22(1), 183-204.

Richardson, W. (2006). Blogs, wikis, podcasts and other powerful web tools for classrooms. Sage Publications Ltd.

Salmon, G. (2008). The future of podcasting. In G. Salmon \& P. Edirisingha (Eds.), Podcasting for learning in universities (pp. 178-187). OUP.

Scagnoli, N. I., Choo, J., \& Tian, J. (2017). Students' insights on the use of video lectures in online classes. British Journal of Educational Technology, 50, 399-414. doi:10.1111/bjet.12572

Seale, J, Boyle, T., Ingraham, B., Roberts, G., \& McAvinia, C. (2007). Designing digital resources for learning. In G. Conole \& M. Oliver (Eds.), Contemporary perspectives in elearning research: Themes, methods and impact on practice (pp. 121-133). Routledge.

Selwyn, N., Gorard, S., \& Furlong, J. (2006). Adult learning in the digital age. Routledge.

Sharples, M., Taylor, J., \& Vavoula, G. (2006). A theory of learning for the mobile age. In R. Andrews \& C. Haythornthwaite (Eds.), The sage handbook of e-learning research (pp. 221247). Sage Publications Ltd.

Smith, R. M. (2008). Conquering the content: A step-by-step guide to online course design. Jossey-Bass.

Song, L., Singleton, S. S., Hill, J. R., \& Koh, M. H. (2004). Improving online learning: Student perceptions of useful and challenging characteristics. Internet and Higher Education, 7, 5970.

Tracy, S. J. (2013). Qualitative research methods. Wiley-Blackwell.

Vonderwell, S. (2003). An examination of asynchronous communication experiences and perspectives of students in an online course: A case study. The Internet and Higher Education, 6(1), 77-90.

Weller, M. (2007). The distance from isolation: Why communities are the logical conclusion in e-learning? Computers \& Education, 49, 148-159. 
Appendix A:

Template of the Initial Questionnaire used in this study

\begin{tabular}{|c|c|c|}
\hline $\begin{array}{l}\text { Question } \\
\text { Number }\end{array}$ & Question Text & Possible responses \\
\hline 01 & $\begin{array}{l}\text { What year of study are you in, on this } \\
\text { MSc course? }\end{array}$ & $\begin{array}{l}1^{\text {st }} \text { year, } 2^{\text {nd }} \text { year or } 3^{\text {rd }} \\
\text { year. }\end{array}$ \\
\hline 02 & $\begin{array}{l}\text { Rate the extent that you have used the } \\
\text { listed online learning resources } \\
\text { provided by this MSc course. }\end{array}$ & $\begin{array}{l}\text { Rating of } 1 \text { (low use) to } \\
5 \text { (high use) for all } \\
\text { named resources. }\end{array}$ \\
\hline 03 & $\begin{array}{l}\text { Rate the existing online learning } \\
\text { resources in terms of their usefulness } \\
\text { to you as a student on the MSc course, } \\
\text { based on how efficient and effective } \\
\text { your learning is from these resources. }\end{array}$ & $\begin{array}{l}\text { Rating of } 1 \text { (low use) to } \\
5 \text { (high use) for all } \\
\text { named resources. }\end{array}$ \\
\hline 04 & $\begin{array}{l}\text { Of all existing online resources, which } \\
\text { do you use the most? }\end{array}$ & $\begin{array}{l}\text { Students could only } \\
\text { select one type of named } \\
\text { resource. }\end{array}$ \\
\hline 05 & $\begin{array}{l}\text { Why did you use this particular } \\
\text { resource the most? }\end{array}$ & Open question (textbox). \\
\hline 06 & $\begin{array}{l}\text { My research work this year will } \\
\text { involve creating new online resources } \\
\text { for learning which you will have } \\
\text { access to. Some options are } \\
\text { "downloadable", in that you could } \\
\text { download a file and use it when not } \\
\text { connected to the internet. Other options } \\
\text { are not downloadable because an } \\
\text { internet connection is needed at all } \\
\text { times for these resources to work. } \\
\text { What online resources would you } \\
\text { prefer to see created? }\end{array}$ & $\begin{array}{l}\text { Rating of } 1 \text { (low use) to } \\
5 \text { (high use) for all } \\
\text { named options for new } \\
\text { resources. }\end{array}$ \\
\hline
\end{tabular}




\section{Appendix B:}

\section{Template for the semi-structured interviews used in this study}

Your motivations:

- Reasons for taking the course

- Deep or strategic studier?

Your study behavior:

- Study time spent during the week - and pattern

- Your mix of reading, creating and interacting

- Your use of the discussion board

- The biggest benefits from studying online

- The problems with online study that you would like to highlight

Your favored resources:

- What resources do you personally favor to use?

- Why did you favor these? - what was it about them that made them better to use or learn from?

- What course resources were more valuable to you for putting together assignment work, if any?

- What resources do you find you are using the least? - and why is that the case?

- Highlighting essential resources for assignments?

- Rating resources - student ratings? Tutor's guidance?

Future learning resources:

- Would more accessible resources be more useful to you in your studies? - If so, why?

- Would resources you can keep after you leave the course be more attractive to you? If so, why?

- From your perspective, what is a good balance between written materials and audio materials? 50/50?

- In terms of audio materials, do you have a particular preference for audio recordings, audio/visual lectures or videos? If so, why?

- Is there any benefit in having a mix of audio resources, or is it better to standardise these to just one or two types, for consistency in delivery?

- Is there any benefit in putting any audio on a more stable platform (e.g., YouTube)? —or would you find that off-putting? 
Appendix C:

Template of the Final Questionnaire used in this study

\begin{tabular}{|c|c|c|}
\hline $\begin{array}{l}\text { Question } \\
\text { Number }\end{array}$ & Question Text & Possible responses \\
\hline 01 & $\begin{array}{l}\text { Did you use any new online resources that } \\
\text { were created for MR } 4001 \text { this year? If yes, } \\
\text { continue to question } 3 \text {. If no, please just } \\
\text { answer question } 2 \text {. }\end{array}$ & Yes/No. \\
\hline 02 & $\begin{array}{l}\text { What factors caused you not to engage with } \\
\text { these new online resources? }\end{array}$ & $\begin{array}{l}\text { Open question } \\
\text { (textbox). }\end{array}$ \\
\hline 03 & $\begin{array}{l}\text { Intervention One: Which formats of this } \\
\text { resource did you attempt to use? }\end{array}$ & List of formats to tick. \\
\hline 04 & $\begin{array}{l}\text { Intervention One: Please state the format for } \\
\text { this resource that you preferred and why } \\
\text { you had a preference for this format. }\end{array}$ & $\begin{array}{l}\text { Open question } \\
\text { (textbox). }\end{array}$ \\
\hline 05 & $\begin{array}{l}\text { Intervention One: If there were one or more } \\
\text { formats of Alternative Urban Forest Futures } \\
\text { that you avoided using, please explain why } \\
\text { you chose not to try to use that format/those } \\
\text { formats. }\end{array}$ & $\begin{array}{l}\text { Open question } \\
\text { (textbox). }\end{array}$ \\
\hline 06 & $\begin{array}{l}\text { Intervention Two: Which formats from } \\
\text { Session } 12 \text { did you attempt to use? }\end{array}$ & List of formats to tick. \\
\hline 07 & $\begin{array}{l}\text { Intervention Two: Which resources did you } \\
\text { find most useful in terms of ideas or } \\
\text { citations for your assignment work for } \\
\text { MR4001? }\end{array}$ & $\begin{array}{l}\text { List of resources to } \\
\text { tick. }\end{array}$ \\
\hline 08 & $\begin{array}{l}\text { Intervention Two: Which resources did you } \\
\text { prefer in terms of their content? }\end{array}$ & $\begin{array}{l}\text { List of resources to } \\
\text { tick. }\end{array}$ \\
\hline 09 & $\begin{array}{l}\text { Intervention Two: Which resources did you } \\
\text { prefer in terms of their format/media? }\end{array}$ & $\begin{array}{l}\text { List of resources to } \\
\text { tick. }\end{array}$ \\
\hline 10 & $\begin{array}{l}\text { Intervention Two: The audio presentations } \\
\text { did not come with a script in this trial. } \\
\text { Would you have preferred the presentations } \\
\text { to also be supplied with a script? }\end{array}$ & Yes/No. \\
\hline
\end{tabular}




\begin{tabular}{|c|l|l|}
\hline 11 & $\begin{array}{l}\text { Intervention Two: What format of resources } \\
\text { that you tried during this intervention would } \\
\text { you want to see used regularly by tutors of } \\
\text { this online MSc course?-and why did you } \\
\text { find them effective for your learning } \\
\text { purposes? }\end{array}$ & $\begin{array}{l}\text { Open question } \\
\text { (textbox). }\end{array}$ \\
\hline $\mathbf{1 2}$ & $\begin{array}{l}\text { Intervention Two: What resources provided } \\
\text { by this intervention did you not find helpful } \\
\text { or that you did not use at all?-and why did } \\
\text { you not think them effective for your } \\
\text { learning purposes? }\end{array}$ & $\begin{array}{l}\text { Open question } \\
\text { (textbox). }\end{array}$ \\
\hline $\mathbf{1 3}$ & $\begin{array}{l}\text { Intervention Two: Did you think there was } \\
\text { anything missing from this session, or } \\
\text { something that should be added? If so, } \\
\text { please contribute what other resources you } \\
\text { would have liked to be part of this final } \\
\text { session for MR4001. }\end{array}$ & $\begin{array}{l}\text { Open question } \\
\text { (textbox). }\end{array}$ \\
\hline $\mathbf{1 4}$ & $\begin{array}{l}\text { Intervention Two: If you would like to } \\
\text { contribute further thoughts on learning } \\
\text { resources that could be effective for } \\
\text { students studying this online MSc course, } \\
\text { please use the comments box provided } \\
\text { below. }\end{array}$ & $\begin{array}{l}\text { Open question } \\
\text { (textbox). }\end{array}$ \\
\hline
\end{tabular}

